\title{
Micro-Variation within Bizkaiera Basque: Evidence from RCs
}

AGER GONDRA

SUNY - Purchase College

\section{$1 \quad$ Introduction}

This paper establishes the syntactic representation and derivation of relative clause (RC) constructions in the Basque dialect Bizkaiera from a Minimalist approach (Chomsky 2000). First, it identifies two micro-dialects (micro-dialect A and micro-dialect B) within Bizkaiera. Micro-dialect A allows an RC with the external DP being in subject or direct object position and with an indirect object or adjunct gap (1a-b), while micro-dialect B does not (2a-b).

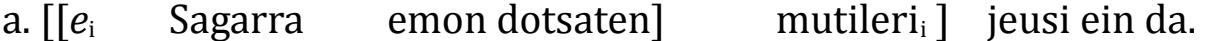
$\emptyset$.DAT apple.D.ABS give aux.A3sD3sE1s-c boy.D.DAT fall do aux.A3s
'The boy that I gave the apple to has fallen down.'

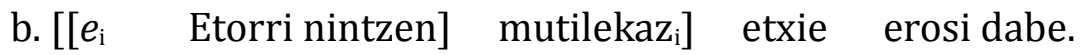
$\emptyset$. Soc come aux.A1s-c boy.D. pl.soc house.D buy aux.A3sE3pl 'The boys that I came with has bought the house.'

(2) a. $\left[\left[e_{\mathrm{i}}\right.\right.$ Sagarra emon dotsaten $] \quad{ }^{*}$ mutileri $_{\mathrm{i}} /{ }^{*}$ mutile $\left._{\mathrm{i}}\right]$ jeusi ein da. ø.DAT apple.D.ABS give aux.A3sD3sE1s-c boy.D.DAT/ boy.D.ABS fall do aux.A3s 'The boy that I gave the apple to has fallen down.'

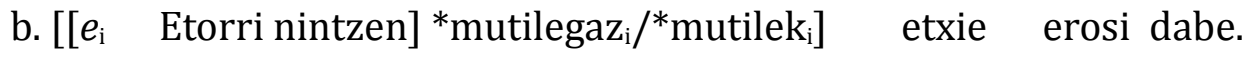
ø.soc come aux.A1s-c boy.D.pl.soc/boy.D.pl.eRG house.D buy aux.A3se3pl 'The boy that I came with has bought the house.'

Second, in order to rule out that this micro-variation arises due to the different syntactic structure observed crosslinguistically, it is shown that both micro-dialects follow the Head raising strategy: $\left.{ }_{\mathrm{DP}}\left[\mathrm{CP}_{\mathrm{DP}} \mathrm{DP}_{\mathrm{i}}\left[\mathrm{c}\left[\mathrm{TP} \ldots \mathrm{t}_{\mathrm{i}} \ldots\right]\right]\right] \mathrm{D}\right]$

Finally, after establishing that Multiple Agree has morphological consequences in Bizkaiera Basque, it is shown that the difference between the micro-dialects under discussion relies on the status of their respective P. In micro-dialect A the $\mathrm{P}$ is a Probe with unvalued D and $\varphi$-features (3a), whereas in micro-dialect B the $\mathrm{P}$ has an unvalued $\mathrm{D}$ feature but lacks unvalued $\varphi$-features (3b).
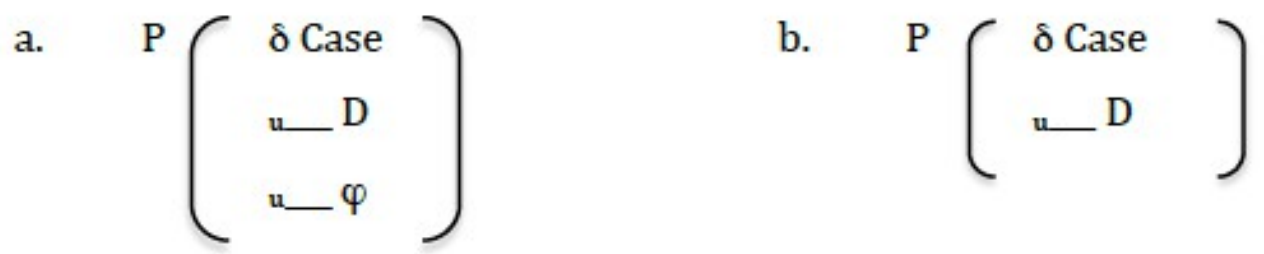
Thus, micro-dialect A can build RCs with the external DP being in subject or direct object position and with an indirect object or adjunct gap (1a-b) due to the unvalued $\varphi$ features in its Ps. Micro-dialect B, on the other hand, cannot build RCs with the external DP being in subject or direct object position and with an indirect object or adjunct gap (2a-b) due to the lack of the unvalued $\varphi$-features on its Ps.

\section{$2 \quad$ Micro-dialects}

In this section two micro-dialects within Bizkaiera dialect are presented: micro-dialect A and micro-dialect B. The evidence for their similarities and differences come from RCs. First the background of the people that speak these micro-dialects is introduced and then the similarities and differences between micro-dialect $\mathrm{A}$ and $\mathrm{B}$ are presented.

\subsection{Speakers of micro-dialect A and micro-dialect B}

In Mundaka, a town in Bizkaia, two micro-dialects can be identified: micro-dialect $\mathrm{A}$ and micro-dialect B. The speakers of both micro-dialect A and micro-dialect B (Group A and Group B, respectively) were born and raised in Mundaka and are native speakers of Spanish and Basque. According Zuazo's (2010) dialectal classification, the Basque dialect that both groups speak is Bizkaiera.

The difference between the two groups relies on the historical context in which they acquired their languages. Group A went to school during Franco's dictatorship (19391975), a time that Basque was banned, and therefore they had Spanish as the only language of instruction. Group B went to school following the establishment of the bilingual educational system, and regarding the model of education it had the Standard Basque as the language of instruction. Thus, they were exposed to and learned the standard variety of Basque from an early age.

\section{$2.2 \quad$ Similarities and differences between the two micro-dialects}

Both micro-dialects can construct RCs when the gap of the relative clause is in a subject (4ac) or object position (4d-f).

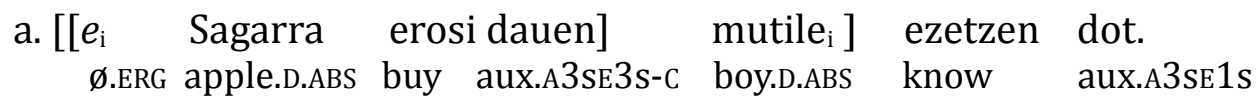
'I know the boy that bought the apple.'

b. $\left[\left[e_{\mathrm{i}}\right.\right.$ Sagarra erosi dauen $]$ mutileri $\left.\mathrm{i}_{\mathrm{i}}\right]$ emon dotsat etxie. ø.ERG apple.D.ABS buy auX.A3sE3s-c boy.D.DAT give auX.A3sD3sE3s house.D.ABS 'I gave the house to the boy that bought the apple.'

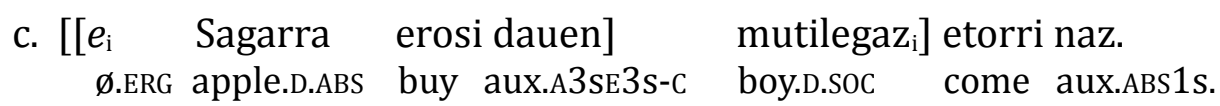
'I came with the boy that bought the apple.' 
d. [[Mutilek $e_{\mathrm{i}}$ erosi dauen] sagarra $]$ jan dot boy.ERG Ø.ABS buy aux.A3sE3s-C apple.ABS eat aux.A3se1s

'I ate the apple that the boy bought.'

e. [[Mutilek $e_{\mathrm{i}}$ erosi dauen] sagarrari $\left.\mathrm{i}_{i}\right]$ ipini dotsat prezidxoa. boy.ERG Ø.ABS buy aux.A3SE3s-c apple.D.DAT put aux.A3sD3sE1s price.D.ABS

'I put the price on the apple that the boy bought.'

f. [[Mutilek $e_{\mathrm{i}}$ erosi dauen $] \quad$ sagarragaz $]$ ein $\operatorname{dot}$ pastela. boy.ERG $\emptyset$.ABS buy aux.A3SE3s-C apple.D.INSTR make aux.A3SE1s cake.D.ABS 'I made the cake with the apple that the boy bought.'

Furthermore, both micro-dialects rule out the RCs in which the external DP is the complement of a different postposition to the one that the Head carries. These are some examples (5a-d):

a. $\left[\left[e_{\mathrm{i}} \quad\right.\right.$ Sagarra emon dotsaten $\quad{ }^{*}$ mutileri $/{ }^{*}{ }^{*}$ mutilegaz $z_{\mathrm{i}}$ korritzen dot. $\emptyset$ ø.DAT apple.D.ABs give aux.A3sD3se1s-c boy.D.DAT/boy.D.SOC run aux.A3sE3s 'I run with the boy that I gave the apple to.'

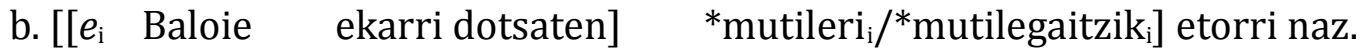
Ø.DAT ball.D.ABS bring aux.A3sD3sE1s-c boy.D.DAT/boy.D.MOT come aux.A1s 'I came because of the boy that I gave the apple to.'

c. $\left[\begin{array}{ll}e_{\mathrm{i}} & \text { Etorri nintzen }] \\ { }^{*} \text { mutilegaz } & /{ }^{*} \text { mutilentzako }\end{array}\right]$ da sagarra.

ø.Soc come aux.A1s-C boy.D.Soc/ boy.D.BEN be.A1s apple.D.ABS

'The apple is for the boy that I came with.'

d. [ $\left[\begin{array}{ll}e_{\mathrm{i}} & \text { Joan nintzen }\end{array}{ }^{*}\right.$ etxera $\mathrm{i}_{\mathrm{i}} \quad /{ }^{*}$ etxiegaitzik $\left.\mathrm{i}_{\mathrm{i}}\right]$ galdetu deu Bitorrek. ø.ALL go aux.A1s-c house.D.Soc/house.D.MOT ask aux.A3E3s. Bitor.ERG 'Bitor asked about the house I went to.'

The difference between the two micro-dialects can be found when the gap is an indirect object or an adjunct and the external DP functions as the subject or object of the main clause. Group A allows RCs with an indirect object or adjunct gap and with the external DP in the subject or direct object position (6a-d). Furthermore, notice that the main auxiliary verb agrees in number with Head of the RC. Group B, on the other hand, does not allow this type of RC (7a-d).

Micro-dialect $A$

a. $\left[\left[e_{\mathrm{i}} \quad\right.\right.$ Sagarra emon dotsaten $] \quad$ neskieri $_{\mathrm{i}} /{ }^{*}$ neskiek $\left._{\mathrm{i}}\right]$ etxie $\varnothing$.DAT apple.D.ABS give aux.A3sD3sE1s-c girl.D.DAT girl.D.ERG house.D.ABS erosi deu. buy aux.A3se3s

'The girl that I gave the apple to bought the house.' 


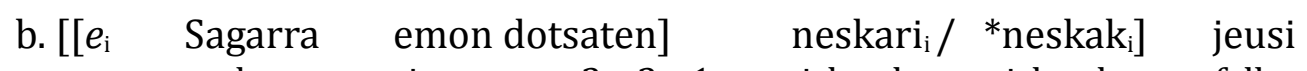
Ø.DAT apple.D.ABS give aux.A3sD3sE1s-c girl.D.pl.DAT girl.D.pl.ABS fall

ein dire.

do aux.A3pl

'The girls that I gave the apple to have fallen down.'

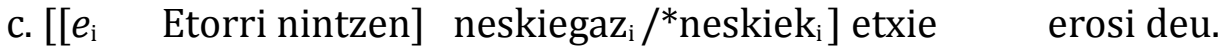

ø.SOC come aux.A1s-C girl.D.SOC girl.D.ERG house.D.ABS buy aux.A3sE3s

'The girl that I came with bought the house.'

d. $\left[\left[e_{\mathrm{i}} \quad\right.\right.$ Etorri nintzen $]$ neskakaz ${ }_{\mathrm{i}} /{ }^{*}$ neskak $\left._{\mathrm{i}}\right]$ jeusi ein dire.

ø.soc come aux.A1s-c girl.D.pl.soc girl.D.pl.ABS fall do aux.A3pl

'The girls I came with have fallen down.'

(7) Micro-dialect $B$

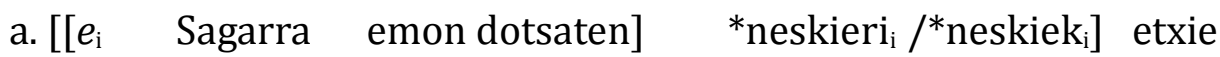

$\varnothing$ Ø.DAT apple.D.ABS give auX.A3SD3SE1s-c girl.D.DAT / girl.D.ERG house.D.ABS

erosi deu.

buy aux.A3se3s

'The girl that I gave the apple to bought the house.'

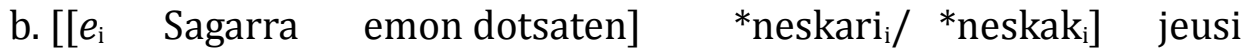

ø.DAT apple.D.ABS give aux.A3sD3sE1s-c girl.D.pl.DAT/girl.D.pl.ABS fall

ein dire.

do aux.A3pl

'The girls that I gave the apple to have fallen down.'

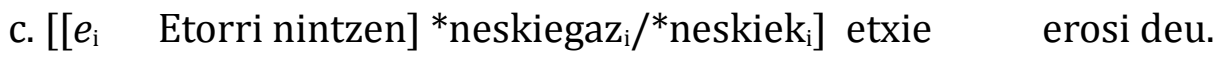

ø.soc come aux.A1s-c girl.D.SOC / girl.D.ERG house.D.ABS buy aux.A3sE3s

'The girl that I came with bought the house.'

d. $\left[\begin{array}{ll}e_{\mathrm{i}} & \text { Etorri nintzen }] \\ { }^{*} \text { neskakaz } & { }^{*}{ }^{n} \text { neskak }\end{array}\right]$ jeusi ein dire.

ø.soc come aux.A1s-C girl.D.pl.soc/girl.D.pl.ABS fall do aux.A3s

'The girls I came with have fallen down.'

A summary of possible relativization in micro-dialect A and in micro-dialect B is shown in Table 1 and Table 2, respectively.

Table 1: Gramaticalization of Relativization in micro-dialect A

\begin{tabular}{|c|c|c|c|}
\hline FG gap FG RC & Subject & Direct Object & Adjunct \\
\hline Subject & $\boldsymbol{v}$ & $\boldsymbol{v}$ & $\boldsymbol{v}$ \\
\hline Direct Object & $\boldsymbol{v}$ & $\boldsymbol{v}$ & $\boldsymbol{v}$ \\
\hline Indirect Object & $\boldsymbol{v}$ & $\boldsymbol{v}$ & $\mathbf{x}$ \\
\hline Adjunct & $\boldsymbol{v}$ & $\boldsymbol{v}$ & $\mathbf{x}$ \\
\hline
\end{tabular}


Table 2: Gramaticalization of Relativization in micro-dialect B

\begin{tabular}{|c|c|c|c|}
\hline FG gap FG RC & Subject & Direct Object & Adjunct \\
\hline Subject & $\boldsymbol{v}$ & $\boldsymbol{v}$ & $\boldsymbol{v}$ \\
\hline Direct Object & $\boldsymbol{v}$ & $\boldsymbol{v}$ & $\boldsymbol{v}$ \\
\hline Indirect Object & $\mathbf{x}$ & $\mathbf{x}$ & $\mathbf{x}$ \\
\hline Adjunct & $\mathbf{x}$ & $\mathbf{x}$ & $\mathbf{x}$ \\
\hline
\end{tabular}

\section{$3 \quad$ Head raising strategy}

In regard to Basque RCs, Oyharçabal (1988), Artiagoitia (1992), and Rebuschi (2003) assume the Head External Analysis (8). In this analysis, RCs are CPs adjoined to the left of the external N-head, reflecting the head-final nature of Basque. In addition, the operator, which is interpreted with the Head outside the RC, moves to the Spec-CP position, leaving a gap in its base-generated position.

(8)

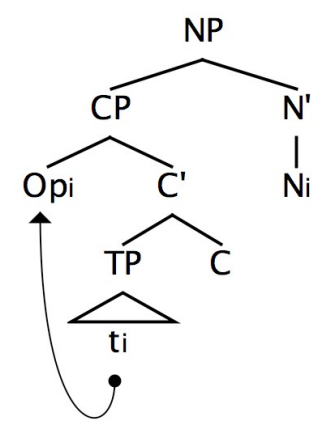

While the Head Raising Analysis is proposed for Standard Basque only by Vicente (2002), it will be shown to be employed in the general Bizkaiera dialect. In this analysis, (9), the CP of RC is a complement to the external D. Moreover, the Head of the RC is basegenerated inside the TP and moved to the Specifier position of the CP.

(9)

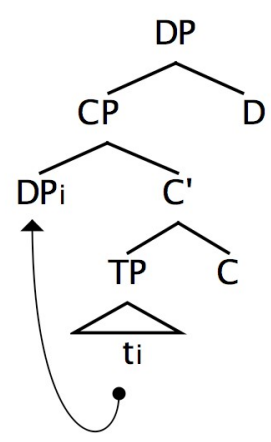

Even though it has not been proposed for Basque, Universal Grammar also provides the Head External strategy with an operator base-generated in the highest Spec-CP position 
from which the operator binds a variable within the TP (Overfelt 2009). This structure is represented in the syntactic tree (10):

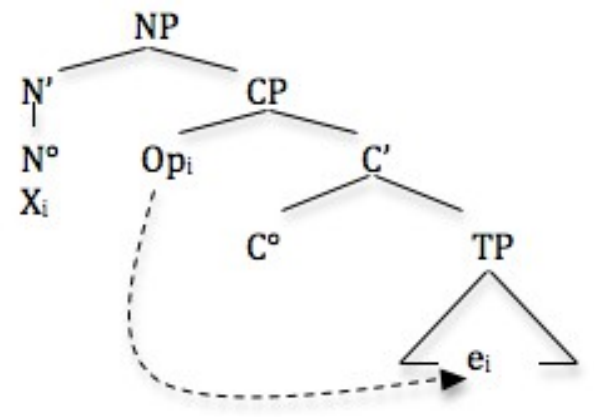

According to Overfelt (2009), in Tigrinya the operator is base-generated in the highest Spec-CP position and it binds a resumptive pronoun in the form of pro occupying the gap position. This is shown in the example (11):

(11) Riti [ ${ }_{\text {ср }} \mathrm{Op}$ [ [тр Nahor [ср siləmintaj $e_{\mathrm{i}}$ nəta dəbdabe tsihifuwa

$\begin{array}{llcl}\text { that-ms } & \text { Nahor why } & e \text { that-fs.ACC } & \text { letter-fs write=GER-S3ms-o3fs } \\ & & & \\ \text { Pilu] } & \text { zigrom]] } & \text { səb?aj } & \text { nəwih ?iju } \\ \text { AUX=s3ms } & \text { REL=wonder=GER-s3ms man-ms } & \text { tall-ms Cop=s3ms }\end{array}$

Intended: 'The man that Nahor wonders why wrote the letter on Monday is tall'.

(Adapted from Overfelt 2009:60)

In this section, it is shown that Bizkaiera Basque follows the Head raising strategy (9) to build RCs. Given that the two proposed micro-dialects show no variation in this respect, no distinction between them are made. First, observing subjacency effects in a RC construction, the Head External Analysis with an operator base-generated in the Spec-CP position (12) is ruled out.

$$
\left[\mathrm{DP}\left[\mathrm{NP}\left[\mathrm{N}^{\prime} \mathrm{N}_{\mathrm{i}} \ldots\right]\left[\mathrm{CqP} \mathrm{Op} \mathrm{p}_{\mathrm{i}}[\mathrm{Tp} \ldots e \mathrm{e} \ldots]\right]\right]\right]
$$

Second, assuming that certain elements are required to hold specific structural relationships with other elements, reconstruction is used to identify the structural relationship between these elements prior to a movement operation. Thus, on the basis of reconstruction effects, scope interaction with quantifiers (Schachter 1973, Vergnaud 1974, Bianchi 1999, Alexiadou et al. 2000, Aoun and Li 2003, Salzmann 2006), idiomatic interpretation (Schachter 1973; Aoun and Li 2003) and pronoun binding (Bianchi 1999, Alexiadou et al. 2000, Bhatt 2002, Aoun and Li 2003, Salzmann 2006) are used to show that the Head of the RC was base-generated inside the embedded clause (13a) and not external to the $\mathrm{CP}(13 \mathrm{~b})$.
a. [DP [CP DP $\left.\left.\mathrm{DP}_{\mathrm{i}}\left[\mathrm{c}\left[\mathrm{TP} \ldots \mathrm{t}_{\mathrm{i}} \ldots\right]\right]\right] \mathrm{D}\right]$
b. [DP $\left.\left[{ }_{N P}\left[N^{\prime} N_{i} \ldots\right]\left[{ }_{C P} O p_{i}\left[T_{P} \ldots t_{i} \ldots\right]\right]\right]\right]$ 


\subsection{Detecting movement}

Whether Bizkaiera requires a movement operation to build RCs is tested by looking at islands within RC constructions. If movement is involved in these constructions, be it overtly as in the Head Raising Analysis (13a) or as in the External Head Analysis with operator movement (13b), island effects will be observed. Thus, for RCs with a gap within an embedded adjunct clause and within a [+Q] embedded clause, ungrammaticality is correctly predicted and therefore, the analysis in which the operator is base-generated in the specifier position of CP (12) is excluded.

According to subjacency, each cycle of movement cannot cross more than one DP or TP, but that the movement needs to take place cyclically (Ross 1967). This restriction on movement creates an island, from which extraction will not be allowed. Thus, extraction out of a [-Q] embedded clause will not create subjacency effects because the intermediate Spec$\mathrm{CP}$ position is not filled and therefore it serves as a landing site for the extracted phrase. This is confirmed in examples (14a-d), in which no subjacency effects are observed when a subject (14a), an indirect object (14b) and adjuncts (14c) are extracted out of a [-Q] embedded clause.

a. $\left[{ }_{\mathrm{CP}}\left[\mathrm{Cr}\left[e_{i} \text { Ure erosiko dauela }\right]_{\mathrm{CP}}\right.\right.$ esan doten $] \quad$ umie $\left._{\mathrm{i}}\right]$ $\varnothing$.ERG water.D.ABS buy.Fut aux.A3se3s.c say aux.A3sE1s-c kid.D.ABS

barreska dau.

laugh aux.A3sE3s

'The boy I said that was going to buy water is laughing.'

b. ${ }_{\mathrm{CP}[\mathrm{CP}}\left[e_{i} \quad \text { Arraine erosi dotsatela }\right]_{\mathrm{CP}}$ esan dauen $]$ andrieri $\left.\mathrm{i}_{\mathrm{i}}\right]$ $\varnothing$. DAT fish.D.ABS buy auX.A3sD3sE1s.c say aux.A3sE3S.C woman.D.DAT

Gernike gusteten jatso.

Gernike.ABs like aux.A3sD3s

'The woman he/she said that I bought the fish from likes Gernika.'

c. ${ }_{\mathrm{Cr}[\mathrm{Cr}}\left[\right.$ Leirek $e_{i}$ atzo korridu bala $]$ pentseten doten $]$ txakurregaz $]$ Leire.ERG $\varnothing . S O C$ yesterday run aux.A3s think aux.A3SE1s.c dog.D.SOC

korridu dot nik geur.

run aux.A3sE1s I.ERG today

'Today I ran with the dog that I think Leire ran with yesterday.'

If Bizkaiera uses movement to build RCs, it is expected to observe subjacency effects in extraction out of [+Q] embedded clauses, as the specifier position of the lower $\mathrm{CP}$ is filled and therefore, the movement is forced to occur across two TPs without respecting cyclic movement. Consider the following sentences (15a-c) with a subject (15a), indirect object (15b) or adjuncts gap (15c) inside a [+Q] embedded clause. 


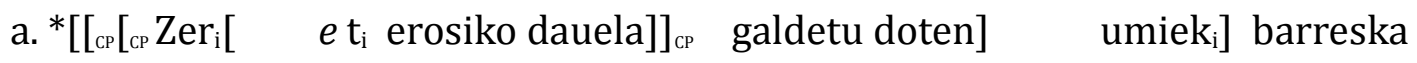
what.ABS $\varnothing$.ERG buy.Fut aux.A3se3s-c ask aux.A3sE1s-c kid.ERG laugh.ABS

dau. auX.A3se3s

*'The boy I asked what was going to buy is laughing.'

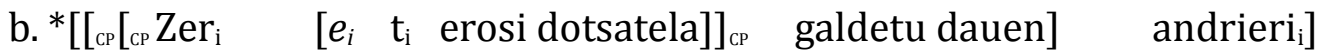
what.ABS $\varnothing$. DAT buy aux.A3sD3sE1s-c ask aux.A3SE3s-c woman.D.DAT

Gernike gusteten jatso.

Gernike.ABs like aux.A3sD3s

*'The woman he/she asked what I bought from likes Gernika.'

c. ${ }^{*}\left[{ }_{\mathrm{cr}}\left[{ }_{\mathrm{cP}}\right.\right.$ Zegaitxik $\mathrm{k}_{\mathrm{i}}\left[\text { Leirek } e_{i} \quad \text { atzo } \mathrm{t}_{\mathrm{i}} \text { k orridu bala }\right]_{\mathrm{CP}} \quad$ galdetzen doten] why Leire.ERG $\varnothing$. SOC yesterday run aux.E3sA3s-c ask aux.A3sE1s-c txakurregaz] korridu dot nik geur. dog.D.SOC run aux.A3sE1s I.ERG today

*'Today I ran with the dog that I asked why Leire ran with yesterday.'

In contrast to (14a-c), the ungrammaticality of examples (15a-c) indicates that there has been a movement involved in the $\mathrm{RC}$ construction. Due to the fact that the intermediate Spec-CP position is occupied, movement could not happen cyclically, but had to cross two TPs, which created subjacency effects.

In conclusion, showing that having a gap inside $[+Q]$ embedded clauses results in ungrammaticality, it is confirmed that movement to the Spec-CP position is involved in the formation of relative clauses in Bizkaiera. Thus, the analysis in which the Head is external to the $\mathrm{CP}$ and the operator is base-generated in the Spec-CP (16) is not a strategy for Bizkaiera Basque RC construction.

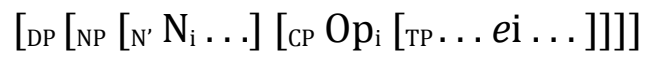

\section{$3.2 \quad$ Headedness}

Ruling out the option of not having movement in the construction of RCs in Bizkaiera, the two possibilities that are left are either the Head Raising Analysis (17a) or the Head External Analysis with operator movement (19b).
a. $\left[{ }_{D P}\left[\mathrm{CP} \mathrm{DP}_{\mathrm{i}}\left[\mathrm{c}\left[\mathrm{TP} \ldots \mathrm{t}_{\mathrm{i}} \ldots\right]\right]\right] \mathrm{D}\right]$
b. $\left[{ }_{D P}\left[{ }_{N P}\left[N^{\prime} N_{i} \ldots\right]\left[\right.\right.\right.$ CPP $\left.\left.\left.O p_{i}\left[{ }_{T P} \ldots t_{i} \ldots\right]\right]\right]\right]$

Syntactic tests related to scope interaction, idioms and pronoun binding are applied to identify the local structural relation between the Head of the RC and the elements inside the TP. Observing that such local relation exists, it is concluded that the Head was basegenerated inside the TP and raised to the Spec-CP (17a). 


\subsubsection{Scope interaction}

The Head Raising Analysis predicts that the Head with an existential quantifier $\exists$ can be interpreted as having narrow scope with respect to the universal quantifier $\forall$ within the relative clause. Bakoitz 'each' has been described as the Basque inherently distributive quantifier (Etxeberria 2012), and it always requires a variable over which to get scope. In fact, when bakoitz 'each' does not have an element syntactically deeper in the structure over which to distribute, or more precisely, a variable over which to get scope, the sentence will result in ungrammaticality (Etxeberria 2001, 2002). Consider the following examples (18a-b):

$$
\begin{aligned}
& \text { a. Ume bakoitzak sagar bat ikusi deu. } \\
& \text { kid each.ERG apple D.Ind.ABS see aux.A3se3s } \\
& \text { 'Each kid saw an apple.' } \\
& \sqrt{\text { distributive; * collective }} \\
& \text { b. *Umiek sagar bakoitza ikusi deu. } \\
& \text { kid.D.ERG apple each.D.ABS see aux.A3sE3s } \\
& \text { 'A kid saw each apple.' } \\
& \text { * distributive; * collective }
\end{aligned}
$$

In (18a) the universal quantifier bakoitz gets scope over a DP headed by an indefinite determiner, which constitutes a variable. In examples (18b), on the contrary, the universal quantifier does not take scope over any variable, and, therefore, the sentence is ungrammatical. Furthermore, as contrastive examples (19a-b) and (20a-b) show, the universal quantifier bakoitz 'each' must be higher in the structure than any existential quantifer due to its wide scope requirement. If bakoitz cannot c-command the existential quantifier, the derivation will crash.

a. Mutil bakoitzak hiru sagar ikusi deuz.

boy each.ERG three apple.ABS saw aux.A3se3pl

'Each kid saw three apples.'

$\sqrt{ }$ distributive; * collective

b. Neska bakoitzak lau mutileri erosi dotsoz.

girl each.ERG four boy.DAT buy auX.A3sD3ple3pl

'Each girl bought (them) from four boys.'

$\sqrt{\text { distributive; * collective }}$

a. *Hiru mutilk sagar bakoitza ikusi dabe.

three boy.ERG apple each.D.ABS see aux.A3ple3s

'Three kids saw each apple.'

* distributive; * collective 
b. *Lau neskak mutil bakoitzari erosi dotsiez.

four girl.ERG boy each.DAT buy aux.A3plD3sE3pl

'Four girls bought (them) from each boy.'

* distributive; * collective

Bakoitz 'each' and an existential quantifier will be used as a test to show reconstruction effects in the relative clause construction in Bizkaiera. The Head Raising Analysis (17a) predicts reconstruction effects and therefore, to be possible to have an existential quantifier within the Head of a RC and bakoitz within the embedded DP subject, while the Head External Analysis (19b) does not. Consider the following sentences (21a-c).

a. [[Mutil bakoitzak $e_{i}$ ekarri dauzen] sagar bidxekazi ] ein dot boy each.ERG $\varnothing$. INS bring aux.A3SE3pl-c apple two.D.INSTR do aux.A3SE1s

pastela.

cake.D.ABS

'I made the cake with the two apples that each kid brought.' $\sqrt{ }$ distributive; * collective

b. [[Neska bakoitzak $e_{i}$ sagarrak erosi dotsozen] lau mutileri $\left.\mathrm{i}_{1}\right]$ girl each.ERG Ø.DAT apple.D.pl.ABS buy aux.A3sD3ple3pl-c four boy.D.DAT

Euskadi gusteten jatzie.

Euskad like aux.A3plD3s

'The four boys that each girl bought an apple for like Euskadi.' $\sqrt{ }$ distributive; * collective

c. [[Pertsona bakoitzak $e_{i}$ korridu ban] hiru txakurrekaz $]$ etorri nai. person each.ERG Ø.SOC run aux.E3SA3s-c three dog.D.SOC come aux.A1s 'I have come with the three dogs that each person ran with.' $\sqrt{ }$ distributive; * collective

In the surface structure of these sentences (21a-d) the existential quantifier is in a position higher than the position of the universal quantifier bakoitz 'each', however, these sentences are grammatical. The grammaticality indicates the Head left a trace in its basegenerated position when it raised to the Spec-CP position and therefore, the universal quantifier within the subject in Spec-TP is able to get scope over the existential quantifier. Thus, the results obtained from the scope interaction are supporting evidence to the claim that RCs in Bizkaiera use the Head raising strategy to construct relative clauses.

\subsubsection{Idioms}

Further evidence in favor of the Head raising strategy in Bizkaiera Basque RC comes from idiom chunk interpretation. Nominal parts of an idioms expression must be generated as the complement of the verb, and cannot be generated independently (Schachter 1973, Verngaud 1974). Consider the following simple sentences the idiom pipper ein 'to cut': 
a. Geur [piper ein] dozu eskolara. today pepper.ABS do aux.A3sE3s school.ELAT 'Today you cut school.'

(Lit: 'Today you have done a pepper to school.')
b. \#piper geur ein dozu eskolara. pepper.ABS today do aux.A3sE3s school.ELAT 'You did a peper to school yesterday.'

In (22a) a local structural relationship between the verb ein 'do' and the object pipper 'pepper' exists, which allows for the idiom to be properly interpreted. In (22b), on the other hand, the object piper 'pepper' is not generated in a local relationship with the verb ein 'do' but independently, which does not allow the idiom expression to be possible.

Under the Head raising Analysis it would be possible to maintain the idiomatic interpretation of the idiom piper ein 'to cut' in a RC with the nominal expression as Head of the RC since the local relationship would be maintained through the trace of the Head. Nevertheless, under the Head External Analysis the idiomatic interpretation would not be possible in a RC with the nominal expression as the Head of the RC given that the nominal expression would be base-generated in its surface position and therefore, the required local relation between piper 'pepper' and the verb would not exist. Consider the following example (23):

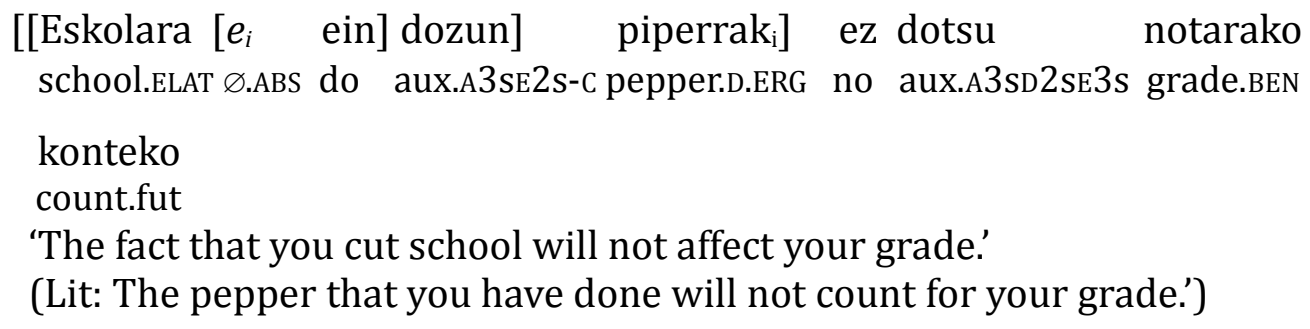

In (23), even though piperrak 'the peppers' is the Head of the relative clause, the sentence still conserves the idiomatic expression. This confirms that the idiom DP-Head of the $\mathrm{RC}$ has raised from the object position of the idiom verb and therefore, that Bizkaiera Basque uses the Head raising strategy to build RCs.

\subsubsection{Pronoun binding}

Pronoun binding is used as the last diagnostic to confirm what it has already been shown via the scope interaction and idioms: Bizkaiera RCs uses the Head raising strategy. As operators can only bind pronouns whose chains they c-command, the premise of this test is that if a pronoun in the Head of the RC can be bound by a universal quantifier within the DP in the embedded Spec-TP position, the relative clause must have a raising analysis (17a). On the contrary, if the Head of the RC originated in its surface position (17b), there would be no copy within the c-command domain of the quantifier and therefore, the quantifier would not bind the pronoun. 
Consider sentences (24a-d), in which the possessive refers solely to the subject because the universal quantifier binds the variable that is within its c-command domain, that is, the possessive is interpreted in the scope of the universal.

a. Mutil bakoitzak bere $_{i}$ sagarra ekarri deu. boy each.ERG poss.3s apple.D.ABS bring aux.A3sE3s

'Each kid brought his/her apple.'

b. Neska guztidxek euren $_{\mathrm{i}}$ liburuek saldu dabez. girl all.ERG poss.3pl book.D.PL.ABS sell aux.A3ple3pl 'All girls have sold their books.'

c. Mediku bakoitzak bere $_{i}$ pazientieri esan dotso etortzeko. doctor each.ERG poss.3s patient.DAT say aux.A3SD3sE3s to.come 'Each doctor has told his/her patient to come.'

d. Pertsona guztidxek euren $_{i} \quad$ txakurrekaz korritzen dabe person all.ERG poss.3pl dog.D.pl.soc run aux.A3se3pl 'All people run with their dogs.'

Showing that a pronoun in the Head position of a RC can be interpreted as a variable bound by a universal quantifier inside the RC is straightforward in a Head Raising Analysis. If there were no operator-variable structure, we would have to infer that the Head was never in the scope domain of the universal quantifier and therefore, Bizkaiera uses the Head external strategy. Consider the following sentences (25a-d).

a. [[Mutil bakoitzak $e_{i}$ ekarri dauen] bere sagarragaz $]$ ein boy each.ERG Ø.ABS bring aux.A3sE3s-c poss.3s apple.D.INST do dot pastela. aux.A3sE3s cake.D.ABS

'I made the cake with his/her apple that each kid brought.'

b. Irakurritxe dekotez [[neska guztidxek $e_{i}$ saldu dabiezen] read have.A3ple1s girl all.ERG Ø.ABS sell aux.A3ple3pl-c euren liburuek $\mathrm{k}_{\mathrm{i}}$. poss.3pl book.D.pl.ABS

'I have read their books that every girl has sold.'

c. [[Mediku bakoitzak $e_{i}$ etortzeko esan dotson] bere pazientieri $\mathrm{i}_{\mathrm{i}}$ ] doctor each.ERG Ø.ABS to.come say aux.A3sD3sE3s-c poss.3s patient.D.DAT

Urdaibai gusteten jatso.

Urdaibai like aux.A3sD3s

'His/her patient that each doctor asked to come likes Urdaibai.' 


\author{
d. [[Pertsona guztidxek $e_{i} \quad$ korridu dabiezen] euren txakurrekazi $]$ \\ person all.ERG Ø.ABS run aux.A3sE3pl-c poss.3pl dog.D.PL.SOC \\ jolastu dot. \\ play be.1s \\ 'I have played with their dogs that every person ran with.'
}

In sentences (25a-d) the pronoun refers to the subject of the RC, which indicates that the bound variable pronoun in the Head of the $\mathrm{RC}$ forces reconstruction to a position where the bound variable is c-commanded by the universal quantifier. Thus, the results obtained from the pronoun binding in these sentences are also evidence of the Head raising strategy for building RCs in Bizkaiera Basque.

\title{
3.2.4 Conclusion
}

Evidence for the Head raising strategy in relative clause constructions of Bizkaiera Basque came from pronoun binding, scope interaction, and idioms, as all of them have shown reconstruction effects. First, the Head of the RC hosting an existential quantifier is interpreted as having narrow scope with respect to the universal quantifier bakoitz 'each' within the embedded clause and therefore, the sentence is grammatical. Second, when the object of an idiom occurs as the Head of the RC that contains the other part of the idiom, the idiomatic reading is still available. Finally, a bound variable pronoun in the Head of the RC forces reconstruction to a position where the bound variable is c-commanded by a universal quantifier.

\section{$4 \quad$ Different types of Ps}

This section shows that the distinct properties in the Ps of micro-dialect A and microdialect $B$ is responsible for the variation observed in (6a-d) and (7a-d). Assuming that the P in Basque is a Probe and that as such it is able to target and Agree with the valued $\mathrm{u}$ features that the P obtained by Agreeing with its DP complement (Řezáč 2008), in this paper it is proposed that the $P$ in micro-dialect $A$ is a Probe with unvalued $D$ and unvalued $\varphi$-features (26a), whereas the P in micro-dialect B is a Probe with just an unvalued D feature (26b).

(26)

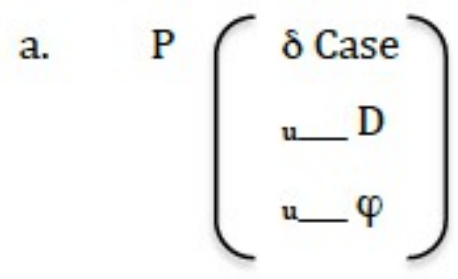

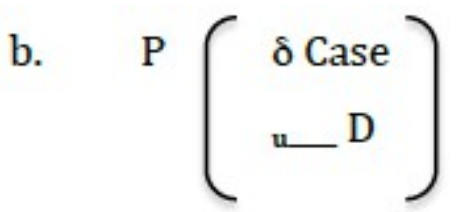

Thus, in a RC construction in micro-dialect A (27a), the external D copies the Case and $\varphi$-features values of the internal $\mathrm{P}$ allowing it to value the $\varphi$-features of the Probe $\mathrm{T} / \nu$. In a RC construction in micro-dialect B (27b), however, the external D copies the Case value of the internal P not allowing it to value the $\varphi$-features of the Probe T/ $v$ and therefore, the derivation crashes. 
a.

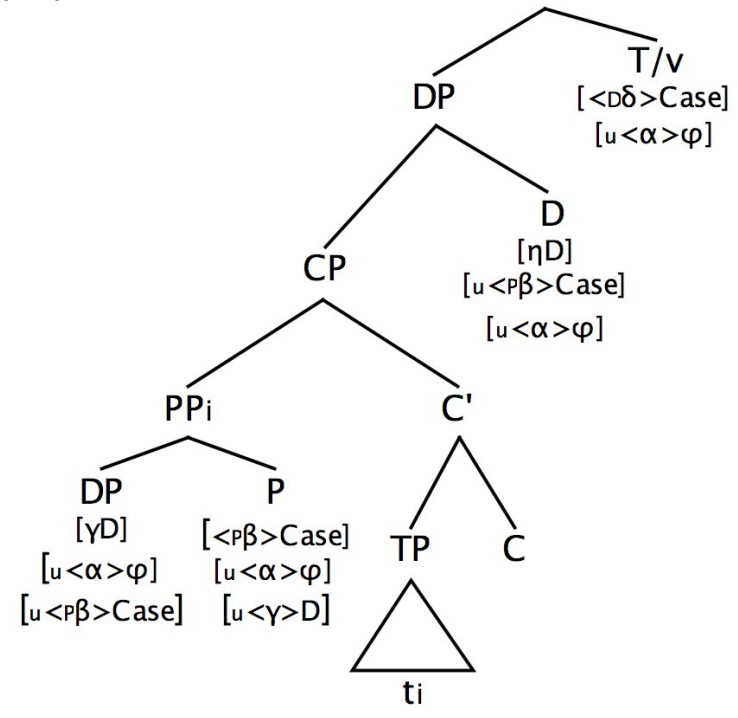

b.

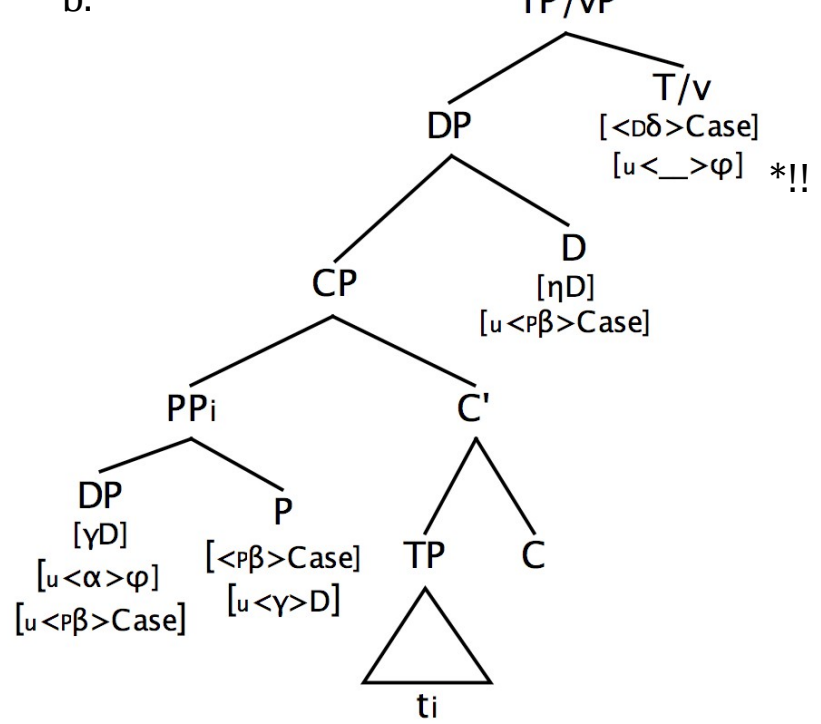

The fact that the two micro-dialects differ in the status of their $P$ is shown via Multiple Agree that occurs in micro-dialect A but it does not in micro-dialect B. In a long distance extraction, the intermediate auxiliary verb in RCs and the main auxiliary verb in Wh-question show agreement in number and person with the extracted PP in micro-dialect A, while they do not in micro-dialect B.

First, this section establishes that in both micro-dialects in a long distance extraction the extracted DP enters into an Agree relation with the intermediate $v$ in a RC and with the highest $v$ in a Wh-question and that in fact this Agree relation has a morphological consequence. Second, it shows that the same phenomenon takes place in a PP long distance extraction in micro-dialect $A$, while it does not in a PP long distance extraction in microdialect B.

\subsection{DP extraction}

Assuming that a relationship exists between Case and agreement (Chomsky 1999, 2000), if Multiple Agree occurs in Bizkaiera Basque, it is predicted that in a DP long distance extraction a higher $v$ Agrees with the extracted DP. Consequently, both the $v$ and the DP get their respective u-features valued: the $\varphi$-features in the $v$ and the Case feature in the DP. Consider a relative construction (28a) and a Wh-question (28b) in Bizkaiera Basque, both built via a long distance extraction:

$$
\begin{aligned}
& \text { a. [CР } \mathrm{t}_{\mathrm{i}}\left[{ } _ { \mathrm { vp } } \mathrm { t } _ { \mathrm { i } } \left[\mathrm { CPP } _ { \mathrm { i } } \mathrm { t } _ { \mathrm { i } } \left[\mathrm{TP}_{\mathrm{TP}} \text { Neskiek } \mathrm{t}_{\mathrm{i}}\right.\right.\right. \text { hartu dauz]-ela] aitsitsek esan] } \\
& \text { girl.D.ERG } \emptyset \text {.ABS take aux.A3ple3s-c grandfather.ERG say } \\
& \text { dauz]-en] sagarrak } \mathrm{k}_{\mathrm{i}} \text { gozoak dire. } \\
& \text { aux.A3ple3s-c apple.D.pl.ABS delicious.D be.A3pl }
\end{aligned}
$$




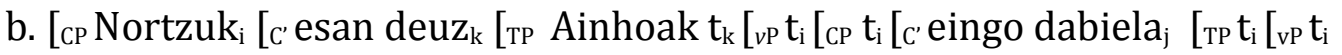 who.ABS.pl say aux.A3ple3s Ainhoa.ERG do.FUT aux.A3sE3pl-c ø.ERG jatekoa $\left.\left.\left.\left.\left.\left.\left.\left.\mathrm{t}_{\mathrm{j}}\right] \mathrm{t}_{\mathrm{j}}\right]\right]\right]\right]\right]\right]\right]$ ? food.D.ABS \\ 'Who did Ainhoa say is going to cook?'}

In (28a), the Head of the RC sagarrak 'apples', which is in plural form, has raised cyclically to the Specifier position of the highest CP. The auxiliary dauz agrees with the Head as its plural number shows, thus this number agreement indicates that the Head sagarrak has Agreed with $v$ during its cyclic-movement. The same can be concluded from (28b). The auxiliary verb deuz is agreeing with the plural Wh- Nortzuk as its absolutive third person plural agreement shows therefore, the highest $v$ entered into an Agree relation with Nortzuk.

In conclusion, Bizkaiera Basque morphology demonstrates that a DP extracted out of an embedded clause enters into an Agree relation with a higher $v$ during its successive cyclic movement. This Agree operation causes the DP to spell-out in absolutive Case, and, what is more important for the purpose of this study, the intermediate auxiliary to spell-out with the person and number features of the extracted DP.

\subsection{PP extraction}

As it has been shown in section 2.2, the variation between the two micro-dialects arises when the gap is an adjunct or an indirect object, and the external DP is in a subject or direct object position. RCs in such context are allowed in micro-dialect A (6a-d). The same configuration renders the structure ungrammatical in micro-dialect $B(7 a-d)$.

Confirmation for the claim that the $\mathrm{P}$ of micro-dialect $\mathrm{A}$ has an unvalued $\varphi$-features while the $\mathrm{P}$ of micro-dialect $\mathrm{B}$ does not is observed in a PP long distance extraction. In micro-dialect $\mathrm{A}$ the higher $v$ gets its unvalued $\varphi$-features valued via Agree with the extracted PP, while in micro-dialect B it does not. Consider the sentences (29a-d), which are RCs in micro-dialect A with a gap within a [-Q] embedded clause.

$$
\begin{aligned}
& \text { a. Mutilek } e_{\mathrm{i}} \text { sagarra emon dotsiela aitsitsek esan } \\
& \text { boy.D.ERG Ø.DAT apple.D.ABS give auX.A3sD3ple3s-C grandfather.ERG say } \\
& \begin{array}{lllll}
\text { dauzen } & \text { neskari } & \text { jeusi ein } & \text { dire. } \\
\text { aux.A3plE3s-c } & \text { girl.D.pl.DAT } & \text { fall do aux.3pl }
\end{array}
\end{aligned}
$$

b. Mutile $e_{\mathrm{i}}$ etorri dala Nereak esan dauzen txakurrekaz boy.D.ABS $\emptyset$.soc come aux.A3s-c Nerea.ERG say aux.A3plE3s-c dog.D.pl.INST

politxek dire. pretty.D.pl be.A3pl

'The dogs that Nerea said the boy came with are pretty.'

$$
\begin{array}{lllll}
\text { c. Jaidxe } & e_{\mathrm{i}} & \text { eingo dauela lagunek esan dauzen } \text { hondartzatan }_{\mathrm{i}}
\end{array}
$$


Party.D.ABS Ø.INS do.fut aux.A3sE3s-C friend.D.ERG say aux.A3plE3s-c beach.D.pl.INE

handidxek dire.

big.D.pl be.A3pl

'The beaches where the friends said that (he/she) will have the party are pretty.'

d. Gaztiek $\quad e_{\mathrm{i}} \quad$ urteten dizela esan dauzen tabernatatik $k_{\mathrm{i}}$ young.D.pl.ERG $\emptyset$.ELA leave aux.3pl-c say aux.A3plE3s-c bar.D.pl.ELA

Urdaibaikoak dire.

Urdaibai.LOC.D.pl be.3pl

'The bars that he said the young people leave from are in Urdaibai.'

Notice that in (29a-d) the intermediate auxiliary verb dauz shows agreement with the DP (third person plural) complement of the extracted PP (neskari 'to the girls in (29a), txakurrekaz 'with the dogs' in (29b), hondartzatan 'at the beaches' in (29c) and tabernatatik 'from the bars' in (29d)). This person and number agreement indicates that the intermediate $v$ in (29a-d) gets its unvalued $\varphi$-features valued by Agreeing with the extracted PP. Now consider examples (30a-e) in micro-dialect $\mathrm{B}^{1}$ :
a. Mutilek $e_{\mathrm{i}}$ sagarra emon dotsiela aitsitsek esan
boy.D.ERG Ø.DAT apple.D.ABS give aux.A3sD3ple3s-C grandfather.ERG say
dauen neskari $i_{i}$ itsasoa gusteten jatsie.
aux.A3sE3s-c girl.D.pl.DAT see.D.ABS like aux.A3sD3pl

'The girls that the grandfather said that the boy gave the apple to like the sea.'

b. Mutile $e_{\mathrm{i}}$ etorri dala Nereak esan dauen txakurrekaz

boy.D.ABS Ø.SOC come aux.A3s-c Nerea.ERG say aux.A3sE3s-C dog.D.pl.INST

jolastu dot.

play aux.A3sE1s

'I played with the dogs that Nerea said the boy came with.'

$\begin{array}{llll}\text { c. Jaidxe } e_{\mathrm{i}} \text { eingo dauela lagunek esan dauen hondartzatan } & \end{array}$ Party.D.ABS $\emptyset$.INS do.fut aux.A3sE3s-C friend.D.ERG say auX.A3sE3s-C beach.D.pl.INE

pasieten dot.

walk aux.A3sE3s

'I walk at the beaches the friends said that (he/she) will do the party at.'

d. Gaztiek $e_{\mathrm{i}} \quad$ urteten dizela esan dauen tabernatatik young.D.pl.ERG Ø.ELA leave aux.A3pl-c say aux.A3sE3s-C bar.D.pl.ELA

dator musikie.

come.3s music.D

1For micro-dialect B, examples showing a matching effect are provided because this is the only way this micro-dialect allows relativizitation of PPs. 
'The music comes from the bars that (he) said that the young people leave from.'

As opposed to the previous examples (29), in (30a-d) the auxiliary verb dau shows third person singular agreement even if the DP complement of the extracted PP has third person plural feature (neskari 'to the girls in (30a), txakurrekaz 'with the dogs' in (30b), hondartzatan 'at the beaches' in (30c) and tabernatatik 'from the bars' in (34d)). I take this as evidence to suggest that the intermediate $v$ in $(30 \mathrm{a}-\mathrm{d})$ does not get its unvalued $\varphi$ features valued via Agree with the extracted PP because the P in this micro-dialect B lacks a $\varphi$-features.

Support for the existence of unvalued $\varphi$-features in micro-dialect $A$ and the lack of them in micro-dialect $B$ also comes from Wh- questions. In micro-dialect $A$ extraction out of a [-Q] embedded clause causes the valued $\mathrm{u}-\varphi$-features of the extracted PP to get copied into the higher $v$. In micro-dialect $B$, however, this does not occur. See the following examples in micro-dialect A (31a-d).
a. Nortzuri esan deuz $_{\mathrm{i}}$
aitsitsek
$e_{\mathrm{i}} \quad$ esan dotsatiela
agur? who.pl.DAT say aux.A3plE3s grandfather.ERG Ø.DAT say auX.A3sD3ple1s-c bye 'Who did the grandfather say that I said goodbye to?'

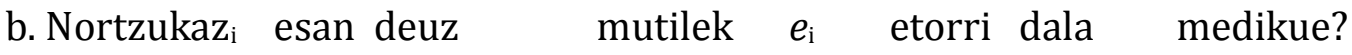 what.pl.soc say aux.A3ple3s boy.D.ERG $\emptyset$.soc come aux.A3s-c doctor 'Who did the boy say the doctor came with?'

c. Ze lekutan $\mathrm{i}_{\mathrm{i}} \quad$ esan deuz Mikelek $e_{\mathrm{i}}$ eingo dauela jaidxe? which place.D.pl.INE say aux.A3ple3s Mikel.ERG Ø.INE do.fut auX.A3sE3s-C party.D 'Which places did Mikel say he will have the part at?'

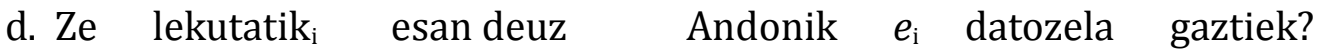
which place.D.pl.ALL say auX.A3plE3s Andoni.ERG Ø.ELA come.A3pl-c young.D.pl.ABS 'Which places did Andoni say the young people come from?'

In (31a-d), the higher auxiliary verb deuz (absolutive third person plural) shows third person plural agreement with the extracted PP (Nortzuri 'to who' in (31a), Zertzukaz 'with what' in (31b), Ze lekutan 'in which places' in (31c), and Ze lekutatik 'from which places' in (31d)). Thus, in the micro-dialect A the $v$ in the matrix clause receives the $\varphi$ values from the extracted PP.

Now observe the following examples in micro-dialect B (32a-d):
a. Nortzuri $i_{i}$ esan deu
aitsitsek
$e_{\mathrm{i}} \quad$ esan dotsatiela
agur? whom.pl.DAT say aux.A3sE3s grandfather.ERG Ø.DAT say aux.A3sD3ple1s-c bye 'Who did the grandfather say that I said goodbye to?'

b. Nortzukaz i esan deu mutilek $e_{\mathrm{i}}$ etorri dala medikue? what.pl.soc say aux.A3sE3s boy.D.ERG $\emptyset$.SOC come aux.A3s-c doctor.D.ABS 'What did the boy say the doctor came with?' 
c. Ze lekutan ${ }_{\mathrm{i}} \quad$ esan deu Mikelek $e_{\mathrm{i}} \quad$ eingo dauela jaidxe? which place.D.pl.INE say auX.A3se3s Mikel.ERG Ø.INE do.fut aux.A3sE3s-c party.D.ABS 'Which places did Mikel say he will go the part at?'

d. Ze lekutatik $\mathrm{k}_{\mathrm{i}}$ esan deu Andonik $e_{\mathrm{i}}$ datozela gaztiek? which place.D.pl.ALl say aux.A3se3s Andoni.ERG Ø.ELA come.3pl-c young.D.pl.ERG 'Which places did Andoni say the young people come from?'

In (32a-e), the higher auxiliary verb deu agrees with third person singular and not with the third person plural of the DP complement of the extracted PP (Nortzuri 'to whom' in (32a), Zertzukaz 'with what' in (32b), Ze lekutan 'in which places' in (32c) and Ze lekutatik 'from which places' in (32d)). Thus, in micro-dialect B the $v$ in the matrix clause does not obtain the $\varphi$-values from the extracted PP since the PP in micro-dialect B lacks unvalued $\varphi$-features that can get valued via Agree with its DP complement.

\subsection{Conclusion}

It was confirmed that the extracted DP and the a higher $v$ enter into an Agree relation by showing that in a DP long distance extraction the intermediate auxiliary verb in a RC and the main auxiliary verb in a Wh-question agrees in person and number with the extracted DP and that the DP is in absolutive Case. In addition, using the morphological consequence of this Agree relation as a test, it was shown that the status of $P$ varies in the two microdialects A: in micro-dialect A Ps have unvalued $\varphi$-features, while in micro-dialect B they lack these features.

\section{Conclusion}

In this paper, first two micro-dialects within Bizkaiera Basque that are spoken by two different generations in Mundaka were identified: Micro-dialect A allows an RC with the external DP being in subject or direct object position and with an indirect object or adjunct gap, while micro-dialect $B$ does not.

Second, in order to rule out that this micro-variation arises due to the different syntactic structure observed crosslinguistically, the reconstruction effects demonstrated that both micro-dialects use the Head raising strategy (33):

$$
\text { [DP } \left.\left[{ }_{\text {CP }} \mathrm{DP}_{\mathrm{i}}\left[\mathrm{c}\left[\mathrm{TP} \ldots \mathrm{t}_{\mathrm{i}} \ldots\right]\right]\right] \mathrm{D}\right]
$$

Finally, given that in a PP long distance extraction the extracted PP enters into an Agree relation with a higher $v$ in micro-dialect $\mathrm{A}$ while it does not in micro-dialect $\mathrm{B}$, it is confirmed that the difference between the two micro-dialects relies on the status of their respective $P$ : in micro-dialect $A$ the $P$ is a Probe with unvalued $D$ and $\varphi$-features (34a), whereas in micro-dialect $\mathrm{B}$ the $\mathrm{P}$ has an unvalued $\mathrm{D}$ feature but not unvalued $\varphi$-features (34b). 

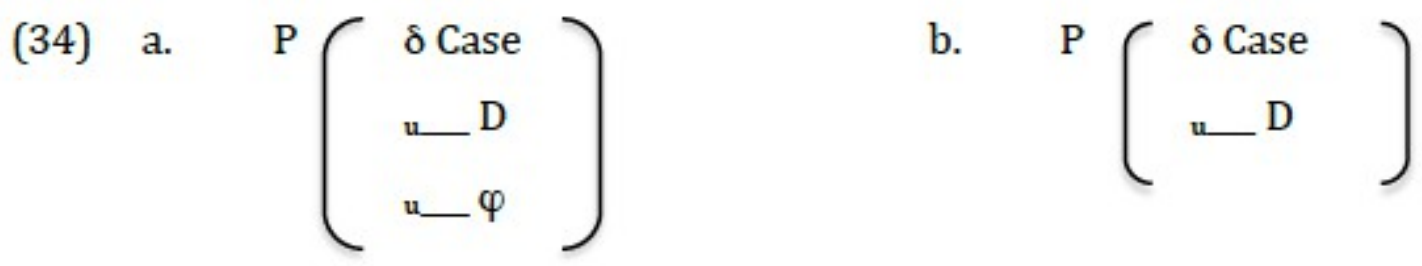

Thus, the existence of the unvalued $\varphi$-features in the $\mathrm{P}$ of micro-dialect $\mathrm{A}$ allows this micro-dialect to build RCs with the external DP being in subject or direct object position and with an indirect object or adjunct gap. The lack of unvalued $\varphi$-features in the $\mathrm{P}$ of micro-dialect $\mathrm{B}$, on the other hand, causes the derivation of $\mathrm{RC}$ with the same configuration to crash.

\section{$5 \quad$ References}

Alexiadou, Artemis, Paul Law, André Meinunger and Chris Wilder. 2000. The Syntax of Relative Clauses. Amsterdam: John Benjamins.

Aoun, Joseph E. and Yen-hui Audre Li. 2003. Essays on the Representational and Derivational Nature of Grammar: The Diversity of Wh- construction. Cambridge, MA: The MIT Press.

Artiagoitia, Xabier. 1992. Why Basque Doesn't Relativise Everything. In Lakarra \& Ortiz de Urbina, eds., Syntax Theory and Basque Syntax, pp. 11-35. San Sebastián: Diputación Foral de Gipuzkoa.

Bianchi, Valentina. 1999. Consequences of Antisymmetry: Head Relative Clauses. Berlin: Mouton de Gruyter.

Chomsky, Noam. 2000. Minimalist inquiries: The framework. In R. Martin, D. Michaels, and J. Uriagereka, eds., Step by Step: Essays on Minimalist Syntax in Honor of Howard Lasnik, pp. 89-159. Cambridge, MA: The MIT Press.

Chomsky, Noam. 1999. Derivation by phase. MIT. ms.

Etxeberria, Urtzi. 2012. Quantification in Basque. In Edward Keenan and Denis Paperno, eds., Handbook of Quantifiers in Natural Languages. Springer.

Etxeberria, Urtzi. 2002. La Interpretación de los Cuantificadores del Euskara. Interlingüística XII:53-70.

Etxeberria, Urtzi. 2001. La Interpretación de Algunos Determinantes Cuantificacionales del Euskara. University of the Basque Country (EHU-UPV). ms.

Kayne, Richard. 1994. The Antisymmetry of Syntax. Cambridge, MA: The MIT Press.

Overfelt, Jason. 2009. The Syntax of Relative Clause Constructions in Tigrinya. MA thesis, Purdue University.

Oyharçabal, Beñat. 1988. Operatzaile isila euskarazko perpaus erlatiboetan. Anuario del Seminario de Filología Vasca 'Julio de Urquijo' 22, pp. 93-97.

Rebuschi, Georges. 2003. Basque Semi-Free Relative Clauses and the Structure of DPs. Lapurdum_8:457-477

Řezáč, Milan. 2008. Phi-Agree and Theta-Relatied Case. In Daniel Harbour, David Adger and Susana Béjar, eds., Phi Theory: Phi-Features Across Modules and Interfaces, pp. 83129. Oxford: Oxford University Press. 
Ross, John R. 1967. Constraints on variables in syntax. PhD dissertation, MIT.

Salzmann, Martin. 2006. Reconstruction in German restrictive relative clauses. In Jeroen van de Weijer and Bettlou Los, eds., Linguistics in the Netherlands 2006, pp. 186-196. Amsterdam: John Benjamins.

Schachter, Paul. 1973. Focus and Relativization. Language 49:19-46.

Vergnaud, Jean-Roger. 1974. French Relative Clauses. PhD dissertation, MIT.

Vicente, Luis. 2002. Prenominal Relatives in Basque and Antisymmetry. BA thesis, University of Deusto.

Zuazo, Koldo. 2010. El euskera y sus dialectos. Alberdania. 